\title{
PERAN GURU BK DALAM MENGIDENTIFIKASI KESULITAN BELAJAR SISWA DI SMA BINA JAYA PALEMBANG
}

\author{
Irma Fitriyanti $^{1}$, M. Ferdiansyah ${ }^{2}$, Arizona $^{3}$ \\ Universitas PGRI Palembang ${ }^{1}$ \\ Email: Irmafitriyanti12@gmail.com \\ Universitas PGRI Palembang ${ }^{2}$ \\ Email: mferdiansyah34@gmail.com \\ Universitas PGRI Palembang ${ }^{3}$ \\ Email: arizonakarno@gmail.com
}

\begin{abstract}
ABSTRAK
Tujuan penelitian ini untuk dimaksud kan untuk mengetahui peran guru Bk dalam mengidentifikasikan kesulitan siswa SMA Bina jaya Palembang. Jumlah popolasi dalam penelitian ini sebanyak 40 siswa, simple penelitian sebanyak 10 siswa, metode yang digunakan dalam penelitian ini adalah kualitatif, teknik pengumpulan data dalam penelitian ini menggunakan observasi, dokumentasi, wawancara, konsioner, yang terlebih dahahulu memberikan prestestts dan selanjutnya diberikan perlakuan posstestts untuk mengetahui hasil dari pembahasan siswa setelah diberikan prilakuan Berdasarkan hasil penelitian di atas dapat peneliti simpulkan bahwa upaya yang dapat dilakukan oleh guru Bk dalam mengindentifaksi masalah kesulitan masalah siswa dengan menggunakan bimbingan kelompok bisa juga dengan mengadakan konsultasi kepada siswa setiap beberapa bulan sekali dengan memanggil satu persatu siswa di setiap kelas dan bertanya kepada siswa tentang masalah yang di hadapi. Bimbingan kelompok dilakukan untuk memberikan bantuan kepada siswa melalui situasi kelompok, bimbingan kelompok bertujuan untuk mengembangkan kemampuan bersosialisasi, khusus nya kemampuan berkomunikasi peserta didik.
\end{abstract}

Kata Kunci: Guru BK, Kesulitan Belajar

\section{THE ROLE OF THE GUIDANCE AND COUNSELING TEACHER IN IDENTIFYING STUDENT'S LEARNING DIFFICULTES IN SENIOR HIGH SCHOOL BINA JAYA PALEMBANG}

\begin{abstract}
The purpose of this study is to identify the role of the guidance and counseling teacher in identifying the difficulties of the bina jaya palembang high school students. The number of pollutants in this study is 40 students, the simple study of 10 students, the methods used in this study are qualitative, the data collection techniques in this study using observation, documentation, interviews, a questioner, The first one to give prestestts and subsequently is given posstestts treatment to determine the results of student discussion after self-conduct can researchers conclude that the effort that can be made by the bk teacher in creating student difficulties by using group guidance may also be by consulting
\end{abstract}


students every few months by calling each student in each class And ask the students about the problem at hand. The group's guidance is made to provide help to students through the group situation, the group's guidance is intended to develop social skills, his or her learner's communication skills.

\section{Keywords: Guidance And Counseling Teacher, Learning Difficulties}

\section{PENDAHULUAN}

Majunya suatu bangsa salah satunya dipengaruhi oleh faktor pendidikan, yang merupakan upaya untuk menciptakan dan meningkatkan sumber daya alam manusia (SDM) yang pada dasarnya merupakan unsur penting dalam pembangunan suatu bangsa. Pembangunan tidak mungkin berhasil dengan baik tanpa didukung oleh tersedianya sumber daya manusia yang akan memadai dan berkualitas. Hal ini, sebagaimana fungsi pendidikan nasional yang tercantum dalam Undang-Undang Nomor 20 tahun 2003, bahwa pendidikan nasional bangsa yang bermatabat dalam rangka mencerdaskan kehidupan bangsa (Aqib dan Elham, 2008: 23).

Tujuan pendidikan dapat dicapai melalui proses pembelajaran yang di selenggarakan di sekolahsekolah. Hal ini selaras dengan pendapatan Ahmadi dan Sofan, yaitu pembelajran pada hakikatnya adalah proses interaksi antara anak dengan anak, anak dengan sumber belajar dan anak dengan pendidikan (Ahmadi dan Amri, 2011:1). Dalam lingkungan pendidikan, Guru Bimbingan dan Konseling cenderung dihadapkan pada sejumlah siswa yang memiliki perbedaan suatu sama lain. Setiap individu memang tidak ada yang sama, perbedaan individual ini pulalah yang menyebabkan perbedaan tingkah laku belajar dikalang siswa. Perbedaan yang langsung berkaitan dengan proses pembelajaran adalah perbedaan dalam ketekunan belajar. Salah satu perbedaan yang dapat terlihat pada siswa adalah pada saat penyelesaian tugas-tugas yang diberikan oleh guru. Ada pada siswa yang dapat menyelesaikannya dengan cepat dan baik, namun ada jugo yang lamban dan gagal, keadaan dimana soswa tidak dapat menjelankan proses pembelajaran sebagaimana mestinya itulah dinamakan kesulitan belajar.

Kesulitan belajar merupakan keadaan siswa yang tidak dapat belajar sebagaimana mestinya dimana sswa yang tidak dapat belajar secara wajar disebabkan oleh adanya ancaman, hambatan, ataupun gangguan dalam belajar 
(Ahmad dan Supriyono, 2004: 77). Dengan memahami hakikat kesulitan belajar, jumlah dan klasifikasi siswa dapat ditentukan dengan strategi penanggulnganya yang efektif dan efisien. Penyebab kesulitan belajar juga perlu dipahami karena dengan pemahaman tersebut dapat dilakukan usaha-usaha prevensif maupun kuratif.

Banyak faktor yang menyebabkan kesulitan belajar. Kesulitan belajar dalam bentuk mendegarkan, bercakap-cakap, menalar, atau berhitung merupakan kesulitan belajar yang bersifat intrinstik. Kesulitan belajar ini yang bersifat intrinstik tersbut terjadi karena adanya pengaruh faktorfaktor lain seperti pengaruh lingkungan, pembelajaran yang tidak tepat, dan lain sebagainya.

Sekolah merupakan lingkungan yang diciptakan untuk membina peserta didik ke arah tujuan tertentu, khusunya dengan memberikan kesempatan dan keterampilan sebagai kehidupanya dikemudian hari. Penyelenggaraan pendidikan disekolah lebih dikenal dengan pembelajaran, dimana terjadi proses belajar mengajar yang melibatkan banyak faktor, baik faktor guru, pelajaran, bahan atau materi, dan fasilitas maupun lingkungan.

Seorang guru Bimbingan dan Konseling harus mampu mengindentifikasi atau menandai munculnya kesulitan belajar yang dihadapi oleh siswa. Untuk dapat mengindentifikasi munculnya kesulitan belajar, Guru Bimbingan dan Konseling memerlukan seperangkat keterampilan khusus, meskipun secara naluri seorang guru biasanya menyadari munculnya kesulitan belajar pada diri siswanya. Kemampuan mengindentifikasi yang berdasarkan naluri tentu kurang efektif jika dibandingkan dengan pengetahuan yang didasarkan pada penerapan langkah-langkah kesulitan belajar siswa.

Berdasarkan hasil observasi yang peneliti lakukan pada tanggal 20 April 2019 terhadap kegiatan belajar siswa di kelas, ditemukan siswa cenderung bersikap pasif, tidak pernah mengumpulkan tugas, membolos dan bentuk perilaku lainya seperti diam saja ketika ditanya oleh guru dan nilainya selalu rendah. Gejala-gejala siswa yang cenderung kurang baik dan kurang mendukung proses belajar dan pembelajaran perlu mendapatkan perhatian khusus dari guru. Hal ini disebabkan, gejalagejala yang dianggap kurang baik dan tidak selayaknya dilakukan prestasi belajar yang rendah pada dasarnya menunjukkan adanya 
pencapaian prestasi belajar yang rendah pada dasarnya menunjukan adanya hambatan atau kesulitan belajar pada siswa yang bersangkutan. Misalnya, siswa tidak selayaknya atau mengikuti proses pembelajaran, tetapi merasa takut maka hal ini menunjukkan kesulitan belajar, guru ataupun berasal dari bahan pelajaran. Tidak semua kesulitan belajar disebabkan oleh ketiga hal tersebut, terkadang penyebab utamanya bisa berasa hanya dari siswa atau hanya berasal guru, bahkan hanya berasal dari materi pelajaranya. Tetapi tidak menutup kemungkinan kesulitan belajar yang dihadapi siswa merupakan manifestasi dari ketiga faktor tersebut.

Berdasarkan latar belakang di atas, bahwa siswa berkedudukan sebagai objek dalam kegiatan pembelajaran, maka perlu diketahui faktor yang melatar belakangi kesulitan belajar yang dialami oleh siswa. Oleh karena itu, penelitian tertarik untuk melakukan penelitian yang berjudul: "Peran Guru Bk Dalam Mengindentifikasi Kesulitan Belajar Siswa di SMA Bina Jaya Palembang”.

\section{LANDASAN TEORI}

Kesulitan belajar siswa merupakan terjemahan dari istilah Bahasa Inggris yaitu earning disability. Learning artinya belajar, sedangkan disabilty artinya ketidakmampuan, jadi terjemahannya adalah ketidakmampuan belajar.

Namun terjemahan sesunguhnya kurang tepat. Oleh sebab itu digunakan kesulitan belajar (Abdurrahman, 2003:6).

Kesulitan belajar memiliki banyak tipe yang masing-masing membutuhkan diagnosis dan pembekalan yang berbeda-beda yang masing-masing dengan tipe masingmasing, sehingga membuat kesulitan belajar sulit untuk di diklasifikasikan, namun menurut Maryani (2018:22) bahwa secara garis besar kesulitan belajar ini dapat diklasifikasikan kedalam dua kelompok, yaitu sebagai berikut.

1) Kesulitan belajar yang berhubungan dengan perkembangan (development learning disabilitas)

Kesulitan belajar yang berhubungan dengan perkembangan mencakup gangguan motorik dan persepsi, kesulitan belajar dalam bahasa dan komunikasi, kesulitan belajar dalam penyesuai perilaku sosial. Kesulitan dalam perkembangan sering terlihat sebagai kesulitan belajar yang disebabkan oleh keterampilan 
prasyaratan (prerequisitueskill), keterampilan yang diperoleh dengan menguasai suatu keterampilan terlebih dahulu untuk dapat mengatasi keterampilan berikutnya.

2) Kesulitan belajar akademik (academic learning disabilities)

Kesulitan belajar yang termask dalam akademik dapat terlihat dari kegagalan-kegagalan pencapaian prestasi akademik. Kegagalan tersebut meliputi penguasaan keterampilan dalam membaca, menulis dan matematika. Kesulitan belajar akademik ini dapat dideteksi dengan mudah oleh guru maupun orang tua kartika anak gagal dalam menguasai salah satu beberapa kemampuan akademik.

Pelaksanaan tugas pembelajaran, guru tidaj hanya berkewajiban menyajikan materi pelajaran dan mengevaluasi pekerjaan siswa, akan tetapi juga bertanggung jawab terhadap pelaksaan bimbingan belajar. Sebagai pembimbing belajar siswa, guru harus mengadakan pendekatan bukan saja melalui pendekatan instruksional, akan tetapi dibarengi dengan pendekatan yang bersifat pribadi (Personal approach) dalam setiap proses belajar mengajar langsung. Melalui pendekatan pribadi, guru akan secara langsung mengenal dan memahami siswa secara lebih mendalam sehingga dapat memperoleh hasil beljar yang optimal.

Menurut Peraturan Pemerintah Nomor 74 Tahun 2008 Tentang Guru menyebutkan "Guru adalah pendidikan profesional dengan tugas utama mendidik, mengajar, membimbing, melatih, menilai, dan mengevaluasi peserta didik pada pendidikan anak usia dini jalur pendidikan formal, pendidikan dasar, dan pendidikan menengah.

Tugas-tugas guru BK dimaksudkan agar guru Bk mengetahui mengenai tugas-tugasnya dalam pelaksanaan bimbingan dan konseling. Adapun tugas-tugas guru BK/Konselor menurut (2009:114), yaitu: memasyarakatkan kegiatan bimbingan dan konseling, melaksanakan persiapan kegiatan bimbingan dan konseling, melaksanakan layanan pada berbagai bidang bimbingan terhadap sejumlah siswa yang menjadi tanggun jawabnya, melaksanakan kegiatan pendukung layanan bimbingan dan konseling, mengevaluasi proses dan hasil kegiatan layanan bimbingan dan konseling, menganalisis hasil evaluasi, melaksanakan tindak lanjut berdasrkan hasil analisi evaluasi, 
mengadministrasikan kegiatan bimbingan dan konseling dan mempertanggung jawabkan tugas dan kegiatan kepada koordinator guru pembimbing.

Selain memiliki tugas sebagai salah satu pendidikan guru bimbingan dan konseling, menurut Supriatna (2001:238) bahwa guru BK di sekolah memiliki peran dan fungsi sebagai berikut:

a. Membantu peserta didik mengembangkan potensi secara optimal baik dalam bidang akademik maupun sosial pribadi, memperoleh pengalaman belajar yang bermakna di sekolah, serta mengembangkan akses terhadap berbagai peluan dan kesempatan baik di lingkungan sekolah maupun diluar sekolah.

b. Membantu guru memahami peserta didik, mengembangkan proses belajar mengajar yang kondosif serta menangani permasalahan dalam proses pendidikan.

c. Membantu pimpinan sekolah dalam penyediaan informasi dan data tentang potensi dan kondisi peserta didik sebagai dasar pembuatan kebijakan peningkatan mutu penelitian.

d. Membantu pendidikan dan tenaga kependidikan lain dalam memahami peserta didik dan kebutuhan pelayanan.

e. Membantu orang tua memahami potensi dan kondisi peserta didik, tuntunan sekolah serta akses keterlibatan orang tua dalam proses pendidikan.

\section{METODE PENELITIAN}

Pengertian metode penelitian menurut Sugiyono (2012:2) adalah "cara ilmiah untuk mendapatkan data dengan tujuan dan kegunaan tertentu". Adapun metode dalam penelitian adalah penelitian deskriptif kualitatif adalah "penelitian yang dilakukan untuk mengetahui nilai variabel mandiri, baik satu variabel atau lebih (independen) tanpa membuat perbandingan atau penghubungan dengan variabel yang lain”.

Penelitian deskritip kualitatif akan mengdeskripsikan indentifikasi kesulitan belajar siswa dan upaya guru BK dalam mengatasi tersebut.

Teknik pengumpulan data pada penelitian ini adalah wawancara, observasi, dan dokumentasi. Dalam penelitian kualitatif fenomena dapat dimengerti maknanya secara baik, apabila dilakukan interaksi dengan subjek melalui 
wawancara mendalam dan observasi pada pokok masalah dimana kejadiankejadian tersbut berlangung, adapun untuk melengkapi data diperlukan dokumentasi yang berkaitan dengan subjek penelitian berkaitan dengan beberapa bahan yang diperlukan.

Menurut Nasir, dkk (20011:256), wawancara adalah "pertemuan antara dua orang untuk bertukar informasi dan ide melalui tanya jawab sehingga dapat dikonstruksikan makna dalam satu topik". Dalam penelitian ini peneliti menggunakan wawancara tidak terstruktur. Wawancara tidak terstrukur adalah wawancara yang bebas dimana peneliti tidak menggunakan pedoman wawancara yang telah tersusun secara sistematis dan lengkap untuk pengumpulan datanya. Wawancara tidak terstruktur atau terbuka, sering digunakan dalam penelitian pendahuluan atau malahan untuk penelitian yang lebih mendalam tentang responden.

Menurut Sugiyono (2011:2003), Observasi adalah "suatu proses yang kompleks, suatu proses yang tersusun dari berbagai proses biologis dan psikologis". Dalam melakukan penelitian ini peneliti melakukan observasi awal dan dengan cara mengamati tempat lokasi penelitian, kebiasaan belajar siswa di kelas.

Dokumentasi adalah catatan peristiwa yang sudah berlalu (Sugiyono, 2011:240). Dokumentasi dalam penelitian ini merupakan teknik terakhir dalam pengumpulan data yang bersifat tercetak (Printed) yang bertujuan untuk melengkapi data-data tambahan penelitian, seperti foto-foto kegiatan yang berkaitan dengan mewawancarai narusumber, surat keterangan penelitian, surat ketersediaan sebagai informasi, serta tulisan-tulisan dan sebagainya.

\section{PEMBAHASAN}

Pembahasan merupakan ulasan peneliti terhadap hasil analisis data yang dikaitkan dengan pertanyaan penelitian. Pembahasan sesuai dengan fokus dan subfokus penelitian. Adapun fokus pada penelitian ini yaitu mengkaji proses yang dilakukan guru BK dalam mengidentifikasi kesulitan belajar siswa SMA Bina Jaya Palembang dan melihat bagaimana cara guru BK Mengatasinya. 
Indetifikasi adalah suatu kegiatan yang diarahkan untuk menemukan siswa yang mengalami kesulitan belajar serta untuk mengetahui bagai mana peran guru BK dalam mengatasi kesulitan belajar pada siswa SMA Bina Jaya serta cara, tindakan ataupun arahan yang di berikan guru BK untuk mengatasi kesulitan belajar pada siswa.

\section{Bagaimana Peran Guru BK dalam Mengidentifikasi Kesulitan Belajar Siswa}

Ada beberapa cara yang dapat dilakukan oleh guru BK untuk mengindentifikasi para siswa yang mengalami kesulitan belajar yaitu :

a. Membantu para siswa untuk mengembangkan potensi secara optimal dan baik dalam bidang akademik, sosial, dan pribadi dalam kehidupan sehari-hari. Siswa juga akan mendapat pengalaman belajar yang baik disekolah.

b. Membantu guru untuk memahami peserta didik, mengembangkan proses belajar mengajar yang kondusif serta menangani dengan baik permasalahan yang ada dalam proses pendidikan.

c. Membantu pimpinan sekolah dalam penyediaan informasi dan data tentang potensi dan kondisi peserta didik sebagai dasar pembuatan kebijakan peningkatan mutu penelitian.

d. Membantu pendidikan dan tenaga kependidikan lain dalam memahami peserta didik dan kebutuhan pelayanan.

e. Membantu orang tua untuk memahami kondisi anak serta hal apa yang menjadi keingian anaknya, tuntunan sekolah serta akses keterlibatan orang tua dalam proses pendidikan.

Priandika menyatakan (2019:62) Dalam hal penanggulangan masalah kesulitan belajar siswa, selain penyampaian materi, nasehat dan informasi yang diberikan oleh siswa, guru bimbingan dan konseling juga harus menjalin kerjasama dengan pihakpihak yang terkait di sekolah seperti wali kelas, guru mata pelajaran, dan juga siswa itu sendiri agar pelaksanaan bimbingan konseling dapat berjalan dengan baik dan diharapkan bisa mencegah, memperbaiki serta menangani kesulitan belajar. 


\section{Instrumen Apa yang Digunakan Guru BK dalam Proses Indentifkasi Kesulitan Belajar Siswa}

Untuk mengindentifikasi siswa yang mengalami kesulitan belajar yaitu dengan cara guru BK mengadakan konsultasi kepada siswa setiap beberapa bulan sekali dengan memanggil satu per satu siswa di setiap kelas dan bertanya kepada siswa tentang masalah yang sedang di hadapi. Guru BK juga dapat mengajak para siswa untuk bimbingan secara berkelompok dan memberikan arahan

yang baik kepada siswa. Hal ini sejalan dengan pengrtian dan tujuan bimbingan kelompok itu sendiri.

Syamsu Yusuf (2006 : 50) mengatakan bimbingan kelompok merupakan pemberian bantuan kepada siswa melalui situasi kelompok. Masalah yang dibahas dalam bimbingan kelompok adalah yang bersifat common problem, masalah yang dialami bersama dan tidak rahasia, baik menyangkut masalah pribadi, sosial, belajar, maupun karir. Secara umum layanan bimbingan kelompok bertujuan untuk pengembangan kemampuan bersosialisasi, khususnya kemampuan berkomunikasi peserta layanan (peserta didik). Secara lebih khusus, layanan bimbingan kelompok bertujuan untuk mendorong pengembangan perasaan, pikiran, persepsi, wawasan dan sikap yang menunjang perwujudan tingkah laku yang lebih efektif, yakni peningkatan kemampuan berkomunikasi baik verbal maupun nonverbal pada peserta didik. Dalam pelaksanaan layanan bimbingan kelompok ada beberapa metode yang dapat diterapkan sesuai dengan kebutuhan dan permasalahannya. Salah satu metode yang dapat digunakan dalam mengentaskan masalah belajar peserta didik yaitu metode pemberian tugas.

\section{Upaya Apa Saja yang Telah Dilakukan oleh Guru BK dalam Mengatasi Kesulitan Belajar Siswa}

Upaya yang dapat di lakukan guru BK untuk mengatasi kesulitan belajar siswa yaitu dengan cara melakukan bimbingan konseling kepada para siswa secara 
rutin kepada siswa yang mengalami permasalahan kesulitan belajar maupun yang mempunyai masalah keluarga. Guru BK dapat memberi arahan, masukan serta semangat kepada siswa yang sedang menghadapi masalah sehingga siswa tersebut mendapatkan perhatian dan kenyamanan. Sehingga siswa tersebut terbuka dan ingin menceritakan permasalahan para siswa.

Matondang (2019: 55) mengatakan bahwa untuk mengatasi kesulitan belajar siswa dapat disimpulkan sebagai berikut: (1) Siswa lebih termotivasi dan terarah dalam belajar. Setelah guru bimbingan dan konseling melakukan berbagai upaya untuk mengatasi kesulitan belajar maka diperoleh hasil belajar bahwa peranan guru bimbingan dan konseling sangat memotivasi siswa untuk lebih giat belajar. Melalui bimbingan dan konseling yang dilakukan siswa menjadi lebih bersemangat dalam belajar menuju kesuksesan. (2) Siswa merasa lebih diperhatikan melalui bimbingan dan konseling oleh guru bimbingan dan konseling terhadap siswa yang mengalami masalah kesulitan belajar, maka siswa tersebut merasa mendapat perhatian seperti siswasiswa yang lain. Dan setelah mereka dibimbing oleh guru bimbingan dan konseling, akhirnya timbul tekad untuk belajar dan memperbaiki hasil belajar mereka. (3) Nilai dan prestasi meningkat. Bimbingan yang dilakukan guru bimbingandan konseling dalam mengatasi kesulitan belajar siswa cukup efektif dan mampu menimbulkan perubahan yang cukup baik pada hasil belajar siswa. Dan membuat siswa menjadi termotivasi untuk mengubah cara belajar yang lebih baik lagi dari sebelumnya.

Berdasarkan hasil penelitian diatas dapat peneliti simpulkan bahwa upaya yang dapat dilakukan oleh guru Bk dalam mengindentifaksi masalah kesulitan masalah siswa dengan menggunakan bimbingan kelompok bisa juga dengan msengadakan konsultasi kepada siswa setiap beberapa bulan sekali dengan memanggil satu persatu siswa di setiap kelas dan bertanya kepada siswa tentang masalah yang di hadapi. Bimbingan kelompok dilakukan untuk memberikan bantuan kepada siswa melalui situasi kelompok, bimbingan kelompok bertujuan 
untuk mengembangkan kemampuan bersosialisasi, khusus nya kemampuan berkomunikasi peserta didik.

Upaya yang dilakukan guru BK siswa dapat termotivasi dan terarah dalam belajar, siswa juga merasa di perhatikan melalui bimbingan dan konseling terhadap siswa yang mengalami kesulitan belajar maka siswa tersebut merasa mendapatkan perhatian seperti siswasiwa yang lain, nilai dan prestasi meningkat.

Bimbingan dikelompok yang dilakukan oleh guru BK dalam mengatasi kesulitan belajar siswa cukup efektip dan mampu membuat perubahan yang cukup baik pada hasil belajar siswa dan membuat siswa menjadi termotivasi untuk mengubah cara belajar lebih baik lagi dari sebelumnya. Hal ini dapat di ketahui dari hasil wawancara yang di lakukan peneliti dengan guru BK di sekolah.

\section{KESIMPULAN}

Berdasarkan hasil dari penelitian diatas, maka dapat peneliti simpulkan sebagai berikut:

1) Cara yang dapat guru BK lakukan untuk mengidentifikasi kesulitan belajar siswa adalah: Membantu para siswa untuk mengembangkan potensi secara optimal dan baik dalam bidang akademik, sosial, dan pribadi dalam kehidupan sehari-hari,

Membantu guru untuk memahami peserta didik, mengembangkan proses belajar mengajar yang kondusif serta menangani dengan baik permasalahan yang ada dalam proses pendidikan, Membantu pimpinan sekolah dalam penyediaan informasi dan data tentang potensi dan kondisi peserta didik sebagai dasar pembuatan kebijakan peningkatan mutu penelitian, Membantu pendidikan dan tenaga kependidikan lain dalam memahami peserta didik dan kebutuhan pelayanan, Membantu orang tua untuk memahami kondisi anak serta hal apa yang menjadi keingian anaknya, tuntunan sekolah serta akses keterlibatan orang tua dalam proses pendidikan.

2) Untuk mengindentifikasi siswa yang mengalami kesulitan belajar yaitu dengan cara guru BK mengadakan konsultasi kepada siswa setiap beberapa bulan sekali dengan memanggil satu per satu siswa di setiap kelas dan bertanya kepada siswa tentang masalah yang sedang di hadapi. Guru BK juga 
dapat mengajak para siswa untuk bimbingan secara berkelompok dan memberikan arahan yang baik kepada siswa.

3) Upaya yang dapat di lakukan guru BK untuk mengatasi kesulitan belajar siswa yaitu dengan cara melakukan bimbingan konseling kepada para siswa secara rutin kepada siswa yang mengalami permasalahan kesulitan belajar maupun yang mempunyai masalah keluarga. Guru BK dapat memberi arahan, masukan serta semangat kepada siswa yang sedang menghadapi masalah sehingga siswa tersebut mendapatkan perhatian dan kenyamanan.

\section{DAFTAR PUSTAKA}

Abdurrahman, M. 2003. Pendidikan Bagi Anak Berkesulitan Belajar. Jakarta: Rineka Cipta.

Ahmadi, A dan Supriyono. 2004. Psikologi Belajar. Jakarta: Renika Cipta.

Ahmadi, L.K., \& Amri S. 2011. Mengembangkan Pembelajaran IPS Terpadu: Analisis Kritis Tentang Metode, Startegi, Evaluasi dan Media Pembelajaran Bidang Studi Sejarah, Geografi, Ekonomi, Sosiolgi, Antarplogi dan Isu Pembelajaran IPS Terpadu. Jakarta: Prestasi Pustaka.

Aqib, Z.\& Elham R. 2008. Membangun Profensionalisme Guru dan Pengawai Sekolah. Bandung: Yram Widya.

Aunurahman. 2009. Belajar dan Pembelajaran. Bandung: Alfabeta.

Bungin, B. 2011. Metode Penelitian Kualitatif. Jakarta: Raja Granfindo Persada.

Hakim, T. 2005. Belajar Secara Efektif. Jakarta: Puspa Swara.

Maryani, I. 2018. Model Interverensi Gangguan Kesulitan Belajar. Yogyakarta: K-Media.

Matondang, Munandar. 2019. Upaya Guru Bimbingan dan Konseling Mengatasi Kesulitan Belajar Siswa Smp Negeri 7 Padangsidimpuan. Padangsidimpuan: Jurnal Bimbingan dan Konseling. Vol. 4 No.1

Moleong, L.J. 2012. Metodologi Penelitian Kualitatif Edisi Revisi. Bandung: Remaja Rosdakarya.

Mugiarso, H. 2009. Bimbingan \& Konseling di Sekolah. Semarang: UNNES Presss.

Nasir, A., dkk. 2011. Buku Ajar: Metodologi Penelitian Kesehatan. Yogyakarta: Muha Medika.

Peraturan Bersama Menteri Pendidikan Nasional dan Kepala Badan Kepegawaian Negara Nomor 03/V/PB/2010 Nomor 14 Tahun 2010 Tentang Petunjuk Pelaksanaan Jabatan Funsional Guru dan Angka Kredintya. Jakarta Depdiknas. 
Peraturan Pemerintah No. 74 Tahun 2008 Tentang Guru. Jakarta: Depdiknas.

Priandika, Devi. 2019. Peran Guru Bimbingan Dan Konseling Dalam Menanggulangi Kesulitan Belajar Siswa Di Mtsn 6 Tulungagung. Tulungagung: Skripsi IAIN Tulungagung (Dipulikasikan)

Slameto. 2015.Belajar dan Faktorfaktor yang mempengaruhinya. Jakarta: Renika Cipta.

Sugiyono. , 2011. Metode Penelitian Pendekatan Kuantitatif, Kualitatif, dan $R \& D$. Bandung: Alfabeta.

Sukardi, DK. 2008. Proses Bimbingan dan Konseling di sekolah. Jakarta: Renika Cipta.

Supriatna, M. Bimbingan dan Konseling Berbasis Kompetensi (Orientasi Dasar Pengembangan Profensi Konselor). Jakarta: RajaGrafindo Persada, (2011).

Undang-Undang Republik Indonesia Nomor 20 Tahun 2003 Tentang Sistem Pendidikan Nasional. Jakarta: Depdiknas

Yusmiati. 2016. Studi Kasus Kesulitan Belajar Siswa Yang Tinggal Kelas [Artikel Penelitian], Pontianak: Program Studi Bimbingan dan Konseling Jurusan Ilmu Pendidkan Fakultas Keguruan Dan Ilmu Pendidkan Univeritas Tanjungpura.

Yusuf, S. 2006. Landasan Bimbingan dan Konseling. Bandung : Rosda. 